\title{
Concentrate levels and Saccharomyces cerevisiae affect rumen fluid-associated bacteria numbers in dairy heifers
}

\author{
G.J. Lascano, G.I. Zanton, A.J. Heinrichs
}

\begin{abstract}
A B S T R A C T
Total viable rumen bacteria counts through the use of colony-unit forming assays lack accuracy because they only include culturable bacteria capable of initiating cell division. Thus, bacterial counts can be underestimated. The use of fluorescent characteristics of cell membranes allows flow cytometry to enumerate and distinguish dead from live bacteria cells. The objective of this experiment was to investigate the viable and total ruminal bacteria counts when 3 levels of forage:concentrate in diets were fed at restricted levels with the addition of Saccharomyces cerevisiae (YC). Three cannulated post-pubertal Holstein heifers (age $18 \pm 1.0$ months) were fed corn silage (CS)-based diets in a 3-period (35 d) Latin square design. Heifers were fed the diets for $21 \mathrm{~d}$ with no yeast addition, followed by $14 \mathrm{~d}$ where yeast culture (YC) was added ( $1 \mathrm{~g} / \mathrm{kg}$ as-fed basis); (Yea-Sacc ${ }^{1026}$, Alltech, Inc., Nicholasville, KY). A low concentrate (LC) TMR ( $80 \%$ CS, $20 \%$ concentrate; $12.4 \%$ CP, $35 \%$ NDF), a medium concentrate (MC) TMR (60\% CS, $40 \%$ concentrate; $12.3 \%$ CP. $28 \%$ NDF), and a high concentrate (HC) TMR (40\% CS, 60\% concentrate; $12.6 \% \mathrm{CP}, 25 \% \mathrm{NDF}$ ), were fed once per day. Rumen fluid was sampled $-2,0,2,4,6$, $8,10,12 \mathrm{~h}$ after feeding. Samples were immediately stained with fluorescent dyes using the BacLight kit (Molecular Probes Inc., Eugene, OR) and analyzed with a Coulter XL-MCL single laser flow cytometer. Mean rumen viable bacteria counts linearly increased among treatments $\left(4.96,4.78,6.73 \times 10^{11} \pm 0.53 \times 10^{11}\right.$ cells $\left./ \mathrm{ml} ; P=0.02\right)$ for LC, MC and HC respectively, and YC addition increased number of viable bacteria cells $(P<0.01)$. Total and viable bacteria counts decreased for the first $2 \mathrm{~h}$ after feeding then increased $4 \mathrm{~h}$ post-feeding. Dietary concentrate level and YC can alter rumen bacteria counts as measured by this method.
\end{abstract}

\section{Introduction}

Bacteria cell viability is often referred to its ability to reproduce and to form a colony. Total viable bacteria counts through the use of colony forming unit assays often lack accuracy because they only include culturable bacteria capable to initiate cell division (Davey et al., 2004). In addition, substrate affinity may vary greatly within organisms (Russell and Hespell, 1981) and intermediate states of some bacteria are undetectable and may not be culturable (Berney et al., 2007). Conventional methods of microscopically counting rumen bacteria are laborious and time-consuming. Thus, viable bacterial counts are often not done or may be underestimated. There are several methods that can assess the viability of single cells without culturing cells. For example, Zhang and Fang (2004) showed that cell metabolic activity, an indicator of its viability, can be measured by specific staining procedures or by the integrity of its cell membrane, thus this method can measure live bacteria cells through counting. Methylene blue, a dye that reacts with the oxidoreductases of the viable cells is also often used for this purpose. New methodologies have been developed that enable the recognition of different bacteria types and different degree of activity (Vaque et al., 2001). The use of direct fluorescent labels of bacteria cells seizes this property 
and can provide actual numbers of viable, dead and total bacteria in fluid samples. Fluorescent characteristics of cell membranes allow flow cytometry to enumerate and distinguished dead from live bacteria cells. The kit, LIVE/DEAD BacLight (Molecular Probes Inc., Eugene, OR), was developed recently to detect Gram-negative and Gram-positive bacteria viability and has been used widely to enumerate bacteria in other fields (Boulos et al., 1999; Gasol et al., 1999; Janssen et al., 2002). This kit utilizes two nucleic acid stains: 1) SYTO-9 which penetrates and stains all the cells regardless of their viability and emits green fluorescence; and 2) propidium iodide (PI) that is excluded by intact membranes. Therefore, PI penetrates cells when membrane integrity is compromised and it stains membranes with an intense red fluorescence. This enables viable cells to be stained green and non viable cells red. Membrane integrity is highly correlated to active (high DNA) and inactive (low DNA) bacteria, which at the same time has been interpreted to correspond to live and dead bacteria (Gasol et al., 1999; Vaque et al., 2001).

Changes in bacteria numbers and shifts in the microbial population influenced by modification of diets from roughage to grain have been reported in ruminants (Tajima et al., 2001). Fermentation end products such as volatile fatty acids and microbial protein are the result of the degradation of feed ingredients by the microbial population in the rumen. Thus, nutrients available for absorption can be affected by population sizes of the microbial species in the rumen and have an effect in animal performance (Weimer, 2001) Even though rumen fluid-associated bacteria (FAB) are estimated to be around $30 \%$ of the total population (Miron et al., 2001). Accurate determination of FAB numbers is necessary and can further be applied to particle associated bacteria (PAB) numbers. On the other hand, the use of Saccharomyces cerevisiae as an additive has resulted on changes of microbial population and numbers in the rumen (Mutsvangwa et al., 1992; Wallace, 1996). Therefore, the aim of this experiment was to monitor rumen bacteria numbers and bacteria viability in growing dairy heifers as affected by different ratios of forage to concentrate $(F: C)$ with or without the addition of yeast culture (YC).

\section{Materials and methods}

Animal care procedures were approved by the Pennsylvania State University Institutional Animal Care and Use Committee. Three Holstein dairy heifers (18.0 \pm 1.2 months of age and $449.6 \pm 19.7 \mathrm{~kg}$ BW), each previously fitted with a $10.6 \mathrm{~cm}$ rumen cannula (Bar Diamond, Parma, ID) under anesthesia, were randomly assigned to 1 of 3 treatment sequences in a $3 \times 3$ Latin square design and housed in a mechanically ventilated and environmentally controlled tie stall barn.

Heifers were weighed weekly, with measurements at 0800 and 1800 h, 2 h prior and $8 \mathrm{~h}$ after feeding, except the week immediately prior to intensive sampling. The amount of experimental diet was adjusted weekly, based on the previous $\mathrm{BW}$, to a level formulated to allow $800 \mathrm{~g} / \mathrm{d}$ ADG. Total mixed rations (TMR) contained corn silage as the sole forage source, ground corn, soybean meal and heat-treated soybean meal (Table 1). Diets provided 2.6, 2.7 and $2.8 \mathrm{Mcal} / \mathrm{kg} \mathrm{DM}$ metabolizable energy (ME) for low (LC), medium (MC), and high $(\mathrm{HC})$ concentrate respectively, with a formulated level of
Table 1

Ingredient and nutrient composition of low concentrate (LC), medium concentrate $(\mathrm{MC})$, and high concentrate $(\mathrm{HC})$ rations fed to heifers.

\begin{tabular}{|c|c|c|c|c|}
\hline \multirow[t]{2}{*}{ Composition } & \multicolumn{3}{|c|}{ Treatment } & \multirow[t]{2}{*}{ SE } \\
\hline & LC & MC & $\mathrm{HC}$ & \\
\hline \multicolumn{5}{|l|}{ Ingredients (\% DM) } \\
\hline Corn silage $^{a}$ & 80.00 & 60.00 & 40.00 & . \\
\hline Ground corn & 5.67 & 29.60 & 47.70 & . \\
\hline Soybean meal (SBM) & 9.47 & 9.94 & 9.00 & . \\
\hline Heat treated SBM ${ }^{\mathrm{b}}$ & 1.60 & 0.80 & 0.00 & . \\
\hline Sodium bicarbonate & 0.35 & 0.35 & 0.35 & . \\
\hline High mineral mix ${ }^{\mathrm{c}}$ & 0.00 & 1.23 & 2.95 & . \\
\hline Low mineral mix ${ }^{d}$ & 2.45 & 1.48 & 0.00 & . \\
\hline \multicolumn{5}{|l|}{ Nutrients ${ }^{e}$} \\
\hline DM \% & 41.93 & 50.61 & 56.5 & 1.03 \\
\hline $\mathrm{CP}(\% \mathrm{DM})$ & 12.93 & 12.38 & 13.17 & 0.10 \\
\hline Soluble (\% CP) & 43.65 & 43.65 & 33.84 & 0.76 \\
\hline $\mathrm{ADF} \%$ & 20.45 & 17.93 & 12.97 & 0.19 \\
\hline NDF $\%$ & 34.18 & 30.03 & 23.23 & 0.38 \\
\hline NFC $\%$ & 48.05 & 53.30 & 58.48 & 0.14 \\
\hline TDN \% & 72.13 & 75.13 & 78.63 & 0.11 \\
\hline $\mathrm{ME}, \mathrm{Mcal} / \mathrm{kg} \mathrm{DM}^{\mathrm{f}}$ & 2.63 & 2.72 & 2.84 & 0.00 \\
\hline $\mathrm{Ca} \%$ & 0.38 & 0.37 & 0.36 & 0.02 \\
\hline $\mathrm{P} \%$ & 0.30 & 0.28 & 0.30 & 0.01 \\
\hline $\mathrm{Mg} \%$ & 0.20 & 0.22 & 0.23 & 0.01 \\
\hline $\mathrm{K} \%$ & 1.33 & 1.12 & 1.02 & 0.03 \\
\hline
\end{tabular}

a Corn silage contained: $33.7 \% \mathrm{DM}, 38.4 \% \mathrm{NDF}, 23.9 \% \mathrm{ADF}, 9.1 \% \mathrm{CP}$, and $36.32 \%$ starch on DM basis.

b Turbo meal.

c High mineral mix contained: 7.8\% vitamin E, 2.6\% vitamin ADE, 28.6\% distillers corn with soluble vitamin D, $14.6 \%$ plain salt, $36.5 \%$ limestone, $2.6 \%$ magnesium oxide, $5.7 \%$ trace mineral premix, and $1.6 \%$ selenium premix on a DM basis.

d Low mineral mix contained: $7.4 \%$ vitamin E, 2.5\% vitamin ADE, 28.6\% distillers corn with soluble vitamin D, $13.9 \%$ plain salt, $34.8 \%$ limestone, $6.0 \%$ magnesium oxide, $5.5 \%$ trace mineral premix, and $1.5 \%$ selenium premix on a DM basis.

e $n=6$ composite samples representing 42 samples per treatment taken daily throughout the collection periods.

$\mathrm{f}$ Estimated: metabolizable energy $(\mathrm{ME})=\mathrm{TDN} \times 0.04409 \times 0.82$.

$13 \% \mathrm{CP}$ to target an average daily gain of $800 \mathrm{~g} / \mathrm{d}$. Animals were fed once daily at $1000 \mathrm{~h}$ and no refusals were observed during the trial. Rations were mixed daily in a rotary mixer (Calan Super Data Ranger; American Calan, Northwood, NH) for approximately $5 \mathrm{~min}$. Animal management and feed sampling followed the procedure used by Lascano and Heinrichs (2009). In brief, feedstuffs and TMR samples were collected daily and composited for each period; dried in a forced air oven $\left(55^{\circ} \mathrm{C}\right)$ immediately after collection for $72 \mathrm{~h}$, and stored for further analysis. Changes in BW determined the quantity of TMR received for the following $7 \mathrm{~d}$; however, DM intake was not changed immediately prior to sampling, as that could have increased variation in the results. Heifers had ad libitum access to water and were released $1 \mathrm{~h}$ post-feeding for approximately $1 \mathrm{~h} / \mathrm{d}$ to a paved exercise lot, except on intensive sampling days. Each of the 3 periods of the experiment consisted of $35 \mathrm{~d}$. Heifers were fed treatment diets for $21 \mathrm{~d}$ with no YC addition (14 d of adaptation and $7 \mathrm{~d}$ of sampling); (Yea-Sacc ${ }^{1026}$, Alltech, Inc., Nicholasville, KY), followed by $14 \mathrm{~d}$ when YC was added to the diet [ $7 \mathrm{~d}$ adaptation to YC (Nocek et al., 2002) and $7 \mathrm{~d}$ sampling period].

Rumen samples were taken from 5 locations in the rumen (dorsal, ventral, anterior, caudal, and central) on days 18 and 
32 of each period at $-2,0,2,4,6,8,10,12$ h relative to the $1000 \mathrm{~h}$ feeding. Rumen fluid was strained through 4 layers of cheesecloth; this fluid was then blended on high speed for $60 \mathrm{~s}$ with a blender (Oster ${ }^{\circledR} 18$ speeds) to homogenize and to detach bacteria from feed particles remaining in the fluid. Blended fluid was finally filtered through a $50 \mu \mathrm{m}$ mesh to isolate protozoa (100 $\mu \mathrm{m}$ or more in length; Weimer, 2001) from the $25 \mathrm{~mL}$ sample collected. These samples were immediately taken to the laboratory and processed within 30 min of collection.

From each sample, $5 \mu \mathrm{l}$ aliquots were diluted immediately with $1000 \mu \mathrm{l}$ of phosphate buffered solution (PBS), $20 \mu \mathrm{l}$ of this dilution were again diluted with $1000 \mu \mathrm{l}$ of PBS. To count FAB viable, dead and total bacteria $485 \mu \mathrm{l}$ from this final dilution was stained with LIVE/DEAD ${ }^{\circledR}$ BacLight $^{\mathrm{TM}}$ (Molecular Probes Inc., Eugene, OR). Cell labeling was done with $7 \mu \mathrm{l}$ of a

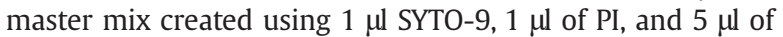
latex beads $\left(3.2 \times 10^{8}\right.$ beads $\left.\mathrm{ml}^{-1}\right)$ as an internal standard (Polysciences, Inc., Warrington, PA). The bead solution was counted at the beginning of every period, and the counts were cross-calibrated (Vaque et al., 2001). This solution was incubated for $10 \mathrm{~min}$ at room temperature $\left(20-22{ }^{\circ} \mathrm{C}\right)$ in the dark to complete the staining and analyzed using a Coulter XL-MCL single laser bench top flow cytometer (Beckman Coulter, Inc. Miami, FL; at the Pennsylvania State University Huck Institute for the Life Sciences) with $488 \mathrm{~nm}$ excitation from a solid state laser. Samples were run at medium speed, and data were acquired in log mode and stopped when 20,000 events, excluding added beads, had been acquired. The rate of particle passage was maintained below 300 events $s^{-1}$ to avoid coincidence. Bacteria were detected in a plot of $90^{\circ}$ light scatter (90LS) vs forward angle light scatter (FALS). Optical filters were set to detect live bacteria with green fluorescence at $520 \mathrm{~nm}$ (FL1) and dead bacteria with red fluorescence at $630 \mathrm{~nm}$ (FL3). The trigger was set for fluorescence in channel FL2. Cytometric noise (debris) can interfere with the determination of dead bacteria. Cells were distinguished from debris in FL1 and FL3 in such a way that live and dead bacteria, stay in a diagonal line while the beads and the debris are allocated in separate parallel lines (Gasol et al., 1999). Software used to get the absolute counts was a Coulter XL2, and counts obtained were then converted to $\mathrm{ml}^{-1}$.

Statistical analysis was conducted using SAS (2006). All dependent variables were analyzed as a $3 \times 3$ Latin square design with the following model: response $=$ overall mean + $\mathrm{F}: \mathrm{C}$ treatment + heifer $+\mathrm{YC}$ (subperiod) + period $+\mathrm{YC} \times \mathrm{F}: \mathrm{C}$ treatment + residual error, where response is the dependent variable. Sources of variation included fixed design effects of period and treatment effects of $\mathrm{F}: \mathrm{C}$ and $\mathrm{YC}$ addition. For measurements repeated within a day, time and fixed effect interactions with time were included as a repeated effect, and heifer was included as a random effect. All denominator degrees of freedom for F-tests were calculated according to Kenward and Roger (1997), and repeated measurements for rumen samples were analyzed including the first autoregressive covariance structure based on the low values received for goodness of fit measures, and Schwartz's Bayesian Criterion. Residual variances were assumed to be normally distributed, and all data are presented as least square means. Because there were no significant $(P>0.05)$ interactions between $\mathrm{F}: \mathrm{C}$ and YC, only the main effect of YC and the $\mathrm{F}: \mathrm{C}$ are reported. Mean separations were determined using the PDIFF statement in PROC MIXED and linear (L) and quadratic (Q) orthogonal contrasts for diet, YC, and hour effects and their interaction were used. For all data treatment effects were considered significant when $P<0.05$ and trends were indicated by $P<0.10$.

\section{Results and discussion}

Table 1 presents the nutrient composition of the diets fed. There was a linear decrease of DMI $(P<0.01)$ as the concentrate level increased. This is a response to the higher energy density of the HC treatments, which reduces DMI required to attain the targeted ADG of $800 \mathrm{~g} / \mathrm{d}$. Nutrient intake is reported in a companion paper (Lascano and Heinrichs, 2009). In brief, diets provided $\pm 60 \mathrm{~g} / \mathrm{d}$ of $\mathrm{CP}$ compared to the CP requirement according to NRC (2001; and provided 1040, 1030 and $1140 \mathrm{~g} / \mathrm{d}$ of CP respectively). Dietary NDF intake was reduced as $F: C$ decreased, which resulted in more non-fiber carbohydrates $(P<0.01)$ and less NDF $(P<0.01)$ consumed by HC heifers. Minerals resulted in some differences among diets, due to the different intakes, but in all diets they were within the mineral recommendations (NRC, 2001), except for potassium which was higher as the proportion of corn silage increased in the experimental treatments (Lascano and Heinrichs, 2009).

This study was conducted only to evaluate bacteria numbers of FAB. However PAB numbers represent around $75 \%$ of the total rumen population (Miron et al., 2001). This fraction consists mainly of bacteria loosely and firmly associated to feed particles (Cecava et al., 1990), and ferment the majority of the feed in the rumen. The PAB can be separated from the substrate by using procedures as blending, chilling, chemical treatment or a combination of these treatments (Cecava et al., 1990). Results from the assessment of ruminal FAB using fluorescent dyes in this study ranged from $10^{11}$ to $10^{12} / \mathrm{ml}$, similar to reported numbers in rumen fluid using traditional counting techniques (Miron et al., 2001). Microbial viability has continuously been plagued by the inability to cultivate bacteria and it has been stated that the culturable count is often 10- to 100-fold lower than the number of cells that would be represented as viable using other methods (Krause and Russell, 1996; Davey et al., 2004). The level of concentrate had a linear effect $(P=0.02)$ on number $\left(4.96,4.78,6.73 \times 10^{11}\right.$ cells $\left./ \mathrm{mL}\right)$ and percentage (83.63, 82.89, 88.53\%) of live bacteria for the LC, MC, and HC respectively (Table 2 ). Increased numbers of bacteria were found by Goetsch and Galyean (1982), when they alternated 55,75 and $80 \%$ of concentrates in continuous culture system and using a direct count using methylene blue dye. Numbers of bacteria cells have been found to be higher in HC in comparison to LC diets (Hespell et al., 1997). But it has to be taken into consideration that number of FAB are higher in high concentrate diets, due to easier enumeration of this fraction in these types of diets. The rumen $\mathrm{pH}$ was not different among treatments (Lascano and Heinrichs, 2009), which means that $\mathrm{pH}$ did not have an effect on bacteria counts. More likely, the increase in viable bacteria numbers is a result of bacteria growing at faster rates with the HC diet or a higher passage rate of heifers fed the LC or MC diet. 
Table 2

Live, dead and total counts of rumen bacteria of dairy heifers fed diets containing low (LC), medium (MC), or high (HC) concentrate and the main effect of the addition (YY) or not (NY) of yeast culture.

\begin{tabular}{|c|c|c|c|c|c|c|c|c|c|c|c|c|}
\hline & \multicolumn{3}{|c|}{$\operatorname{Diet}\left(\mathrm{F}: \mathrm{C}^{\mathrm{c}}\right.$ ratio) } & \multirow[b]{2}{*}{$S E^{d}$} & \multicolumn{2}{|l|}{ Yeast } & \multirow[b]{2}{*}{$\mathrm{SE}^{\mathrm{d}}$} & \multicolumn{5}{|c|}{$P$ value } \\
\hline & $\mathrm{LC}$ & $\mathrm{MC}$ & $\mathrm{HC}$ & & NY & YY & & $\mathrm{YC}^{\mathrm{e}}$ & $\mathrm{F}^{\mathrm{f}}$ & $\mathrm{F}^{\mathrm{g}}$ & Hour $^{g}$ & $\mathrm{H}_{\mathrm{xYC}}{ }^{\mathrm{g}}$ \\
\hline \multicolumn{13}{|l|}{$\left(10^{11} / \mathrm{mL}\right)$} \\
\hline Live & $4.96^{\mathrm{b}}$ & $4.78^{b}$ & $6.73^{\mathrm{a}}$ & 0.44 & 4.24 & 6.74 & 0.36 & $<0.01$ & 0.02 & 0.08 & $<0.01$ & 0.02 \\
\hline Dead & $0.94^{\mathrm{ab}}$ & $0.87^{\mathrm{ab}}$ & $0.81^{\mathrm{b}}$ & 0.07 & 0.79 & 0.95 & 0.05 & 0.07 & 0.20 & 0.97 & 0.12 & 0.27 \\
\hline Total & $5.90^{b}$ & $5.65^{b}$ & $7.62^{a}$ & 0.49 & 5.10 & 7.69 & 0.40 & $<0.01$ & 0.03 & 0.09 & $<0.01$ & 0.02 \\
\hline Live (\%) & $83.63^{b}$ & $82.89^{b}$ & $88.53^{a}$ & 0.08 & 84.21 & 85.83 & 0.09 & $<0.01$ & $<0.01$ & $<0.01$ & $<0.01$ & 0.36 \\
\hline
\end{tabular}

a,b Means in the same row with different superscripts differ $(P<0.05)$.

c Forage-to-concentrate ratio.

d Standard error of the main effects of diet and YC.

e Main effect of YC.

$\mathrm{f}$ Linear effect from increasing proportion of concentrate in the diet.

g Quadratic effect for changing the proportion of concentrate in the diet; quadratic effect of hour; quadratic effect of hour $\times$ YC interaction.

In this experiment the increase in FAB counts was followed by a reduction in ammonia and VFA concentration in the rumen (Lascano and Heinrichs, 2009). A quadratic time effect $(P<0.01)$ was found with live bacteria numbers decreasing after feeding and starting to increase between 4 and $6 \mathrm{~h}$ posteating (Fig. 1). Particle colonization has been found to be extremely rapid and intense after feeding (Miron et al., 2001), and cellulolytic bacteria have decreased more substantially

(a)

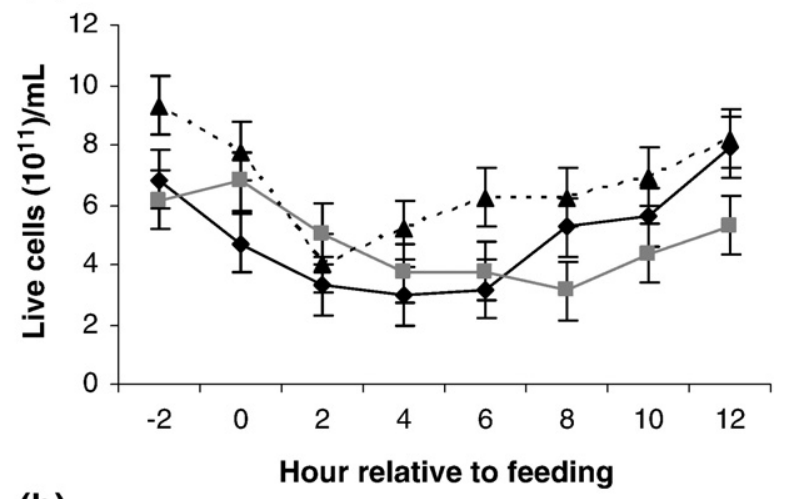

(b)

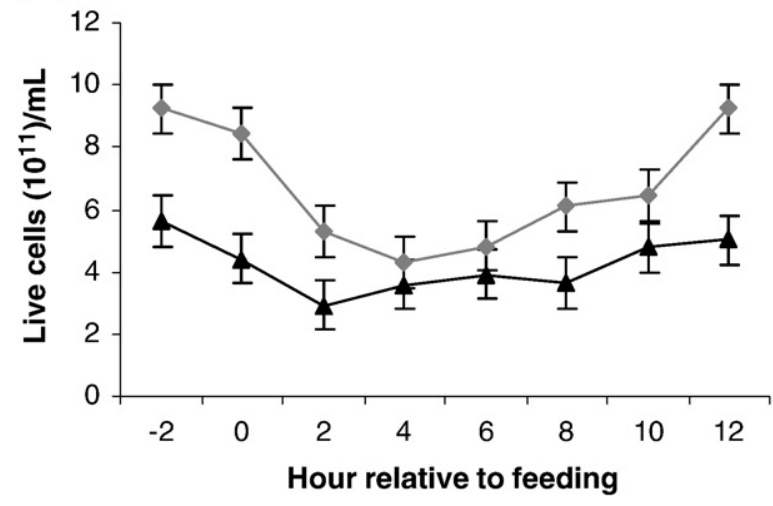

Fig. 1. (a) Live bacteria counts of dairy heifers fed diets containing low (LC; $\diamond$ ), medium (MC; ), or high (HC; $\mathbf{\Delta}$ ) concentrate and (b) the effect of the addition $(\boldsymbol{)})$ or not $(\mathbf{\Delta})$ of yeast culture before and after feeding. when animals have been fed a HC in comparison to LC diet (Leedle et al., 1982). The lowest live bacteria count was $2 \mathrm{~h}$ after feeding and the highest $12 \mathrm{~h}$ after feeding similar to Leedle et al. (1982) and Bryant and Robinson (1968) feeding HC and LC concentrate diets with alfalfa hay as the sole source of forage. Another option to explain this variation is an increase in rumen dilution rate after feeding (Stokes et al., 1985) resulting in higher numbers of FAB passing out of the rumen (Wells and Russell, 1996). Thus, the percentage of PAB cells would be higher with more forage in the diet and numbers of viable bacteria decline in the fluid for this reason. Leedle and Hespell (1984) observed that washing the rumen bacterial population with buffer solution resulted not only on a higher viable count than its unwashed counterpart, but a greater proportion of fiber-digesting bacterial groups were culturable. These researchers interpreted this increase as an increase in the number PAB detached from the feed particles; number of viable bacteria in this experiment ranged from $2.5 \times 10^{8}$ to $7.6 \times 10^{9}$ and direct counts from $7.5 \times 10^{9}$ to $1.29 \times 10^{10}$.

There was no significant interaction between time and ration; but the $\mathrm{pH}$ had a similar pattern within the day with live bacteria numbers (Fig. 1; Lascano and Heinrichs, 2009). Live bacteria numbers have been observed to be the highest (10-fold) just before feeding and decrease (2-fold) postfeeding; it has been difficult to determine if this is a response to $\mathrm{pH}$ and death or simply due to attachment and colonization of feed particles (Wells and Russell, 1996). The post-feeding population decrease may be a suppression of growth of the cellulolityc bacteria species affected by $\mathrm{pH}$ but not from the glucose and starch-fermenting species that have shown no significant changes during the feeding cycle (Leedle et al., 1982). Further research is needed to clarify this result. On the other hand, however, there was a significant time by yeast interaction (Fig. 1b), suggesting that YC increased the rumen microbial population regardless of the possible mechanism involved in the fluctuation of the different $\mathrm{F}: \mathrm{C}$ treatments. The inclusion of YC in the diets increased live bacteria counts (4.24 vs $6.74 \pm 0.36 \times 10^{11}$ cells $/ \mathrm{mL} ; P<0.01$ ). Similar results have been found when YC has been added to diets of dairy cows (Wiedmeier et al., 1987; Harrison et al., 1988). These researchers suggested a bacteria stimulatory effect of vitamins, branched chain fatty acid or metabolic end products provided by the YC. Several authors have found a decrease in 
ruminal ammonia, and attributed this effect to an increase in bacterial activity and population (El Hassan et al., 1996; Roa et al., 1997; Koul et al., 1998). One of the more consistent effects shown with the addition of YC to diets of different kind has been the increase in total and cellulolytic bacteria counts. Higher bacteria populations result in higher rate of fiber degradation and an increase flow of microbial protein from the rumen (Newbold et al., 1996). Low dilution rates give greater opportunity for bacteria to be lysed and turned over (Wells and Russell, 1996). This could be a mechanism through which YC could manipulate and increase the number of dead bacteria $(P=0.07)$, as a response to higher amount total bacteria turning over.

The highest dead bacteria counts were found 4 to 6 h posteating (Fig. 2). It has been determined that some ruminal bacteria could suffer an uncoupled metabolic adaptation to upset conditions, and a phenomenon known as substrate accelerated death may have undertaken the rumen environment (Postgate and Hunter, 1964); increasing the count of dead FAB. Total bacteria numbers followed the same pattern as the viable bacteria counts (Fig. 3). Percentages of live bacteria ranged from 83.63 to $88.53 \%$ (Table 2). There were linear and quadratic effects of $\mathrm{F}: \mathrm{C}(P<0.01)$ in the percentages of live bacteria. There was a significant increase in the percentage of live bacteria as the amount of concentrate in the diet increased.

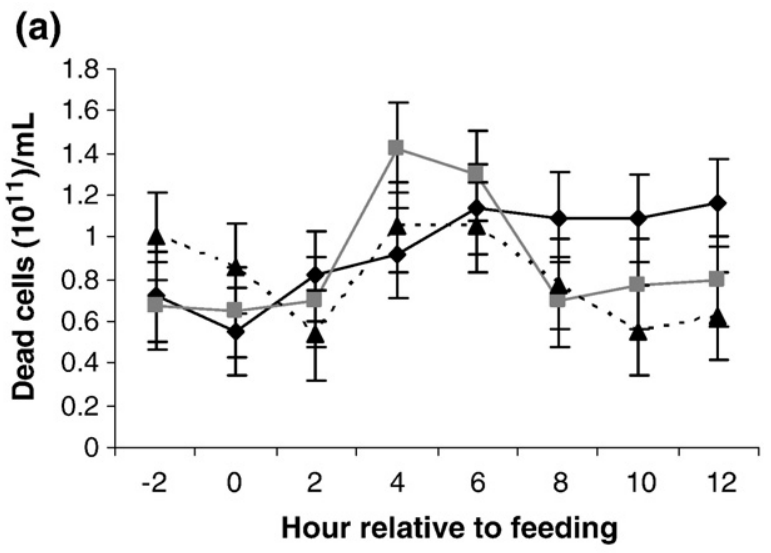

(b)

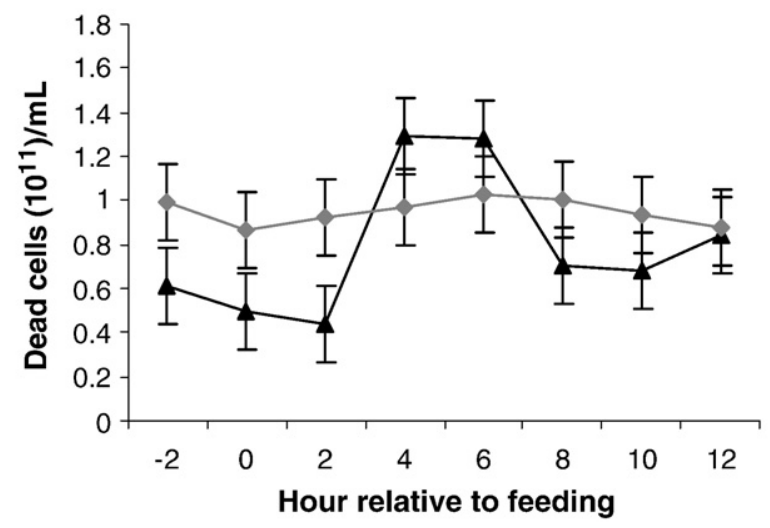

Fig. 2. (a) Dead bacteria counts of dairy heifers fed diets containing low (LC; ), medium (MC; ), or high (HC; $\mathbf{\Delta}$ ) concentrate and (b) the effect of the addition $(\Delta)$ or not $(\mathbf{\Delta})$ of yeast culture before and after feeding. (a)

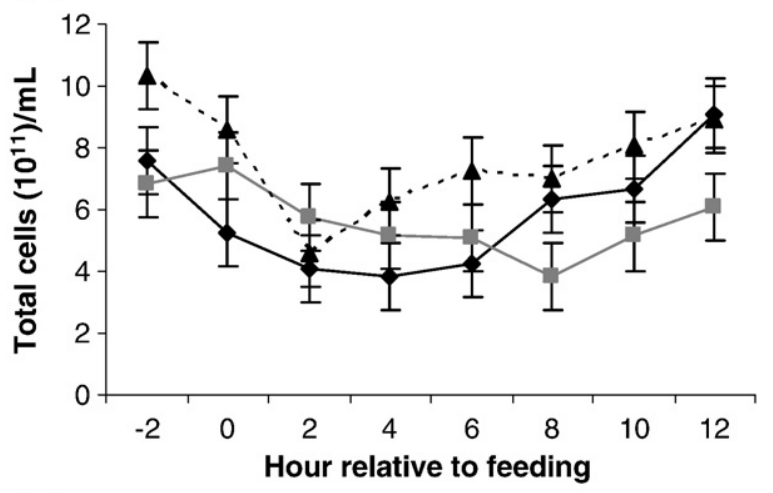

(b)

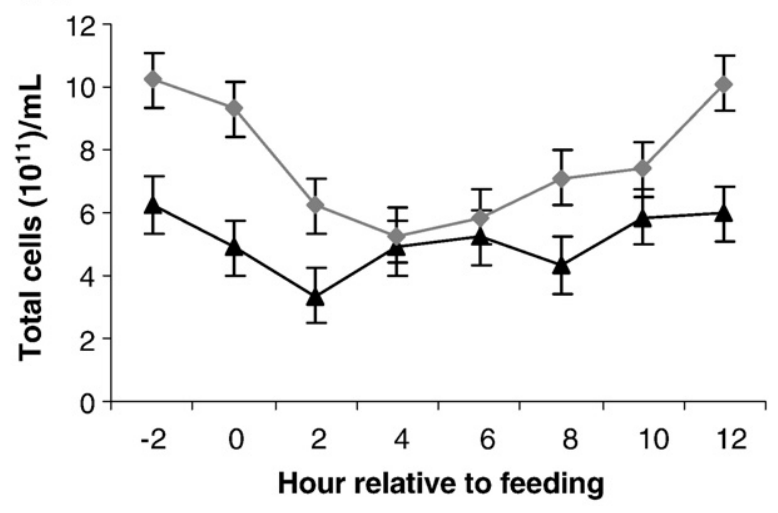

Fig. 3. (a) Total bacteria counts of dairy heifers fed diets containing low (LC; ), medium (MC; ), or high (HC; $\mathbf{\Delta}$ ) concentrate and (b) the effect of the addition $(\Delta)$ or not $(\boldsymbol{\Delta})$ of yeast culture before and after feeding.

\section{Conclusions}

Rumen FAB counts were found to be significantly increased in high concentrate limit fed heifers as well as with the addition of YC to the diets. Time relative to feeding affected total and live bacteria counts. Numbers of FAB observed using flow cytometry were similar to results reported in previous studies using different counting techniques. Using flow cytometry and fluorescent dyes to assess the viability and bacteria counts is a rapid way to determine numbers of rumen bacteria. The use of this technology could be useful to determine quantities and activities of specific rumen microbes in the rumen environment of not only the FAB but also the PAB fraction.

\section{Acknowledgments}

Initial work developing the flow cytometry protocol was in cooperation with Elaine Kunze, Susan Margargee, and Nicole Bem of The Huck Institutes of the Life Sciences, The Pennsylvania State University, each of whom contributed with their expertise in this study. The contribution of the yeast culture and financial support from Alltech Inc. is gratefully acknowledged. 


\section{References}

Berney, M., Hammes, F., Bosshard, F., Weilenmann, H.U., Egli, T., 2007. Assessment and Interpretation of bacterial viability by using the LIVE/ DEAD BacLight Kit in combination with flow cytometry. Appl. Environ. Microbiol. 73, 3283-3290.

Boulos, L., Provost, M., Barbeau, B., Coallier, J., Desjardins, R., 1999. LIVE/DEAD BacLight: application of a new rapid staining method for direct enumeration of viable and total bacteria in drinking water. J. Microbiol. Methods 37, 77-86.

Bryant, M.P., Robinson, I.M., 1968. Effects of diet, time after feeding, and position sampled on numbers of viable bacteria in the bovine rumen. J. Dairy Sci. 51 1950-1955.

Cecava, M.J., Merchen, N.R., Gay, L.C., Berger, L.L., 1990. Composition of rumina bacteria harvested from steers as influenced by dietary energy level, feeding frequency, and isolation techniques. J. Dairy Sci. 73, 2480-2488.

Davey, H.M., Kell, D.B., Weichart, D.H., Kaprelyants, A.S., 2004. Estimation of microbial viability using flow cytometry. Curr. Prot. Cyto. 29, 11,301-11,321.

El Hassan, S.M., Newbold, C.J., Edwards, I.E., Topps, J.H., Wallace, R.J., 1996. Effect of yeast culture on rumen fermentation, microbial protein flow from the rumen and live-weight gain in bulls given high cereal diets. Anim. Sci. 62, 43-48.

Gasol, J.M., Zweifel, U.L., Peters, F., Fuhrman, J.A., Hagstrom, A., 1999 Significance of size and nucleic acid content heterogeneity as measured by flow cytometry in natural planktonic bacteria. Appl. Environ. Microbiol. 65, 4475-4483.

Goetsch, A.L., Galyean, M.L., 1982. Effects of alternating high and medium concentrate diets on fermentation in a semi-continuous rumen culture system. J. Dairy Sci. 65, 675-679.

Harrison, G.A., Hemken, R.W., Dawson, K.A., 1988. Influence of addition of yeast culture supplement to diets of lactating cows on ruminal fermentation and microbial populations. J. Dairy Sci. 71, 2967-2975.

Hespell, R.B., Akin, D.E., Dehority, B.A., 1997. Bacteria, fungi and protozoa of the rumen. Gastrointestinal Microbes and Host Interactions. International Thompson Press, New York.

Janssen, P.H., Yates, P.S., Grinton, B.E., Taylor, P.M., Sait, M., 2002. Improved culturability of soil bacteria and isolation in pure culture of novel members of the divisions acidobacteria, actinobacteria, proteobacteria, and verrucomicrobia. Appl. Environ. Microbiol. 68, 2391-2396.

Kenward, M.G., Roger, J.H., 1997. Small sample inference for fixed effects from restricted maximum likelihood. Biometrics 53, 983-997.

Koul, V., Kumar, U., Sareen, V.K., Singh, S., 1998. Mode of action of yeast culture (YEA-SACC 1026) for stimulation of rumen fermentation in buffalo calves. J. Sci. Food Agric. 77, 407-413.

Krause, D.O., Russell, J.B., 1996. How many ruminal bacteria are there? J. Dairy Sci. 79, 1467-1475.

Lascano, G.J., Heinrichs, A.J., 2009. Rumen fermentation pattern of dairy heifers fed restricted amounts of high, medium, and low concentrate diets with and without Saccharomyces Cerevisiae. Livest. Sci. 124, 48-57.

Leedle, J.A., Hespell, R.B., 1984. Changes of bacterial numbers and carbohydrate fermenting groups during in vitro rumen incubations with feedstuff materials. J. Dairy Sci. 67, 808-816.
Leedle, J.A., Bryant, M.P., Hespell, R.B., 1982. Diurnal variations in bacterial numbers and fluid parameters in ruminal contents of animals fed low-or high-forage diets. Appl. Environ. Microbiol. 44, 402-412.

Miron, J., Ben-Ghedalia, D., Morrison, M., 2001. Invited review: adhesion mechanisms of rumen cellulolytic bacteria. J. Dairy Sci. 84, 1294-1309.

Mutsvangwa, T., Edwards, I.E., Topps, J.H., Paterson, G.F.M., 1992. The effect of dietary inclusion of yeast culture (Yea-Sacc) on patterns of rumen fermentation, food intake and growth of intensively fed bulls. Anim. Prod. 55, 35-40.

Newbold, C.J., Wallace, R.J., McIntosh, F.M., 1996. Mode of action of the yeast Saccharomyces cerevisiae as a fed additive for ruminants. Br. J. Nutr. 76, 249-261.

Nocek, J.E., Kautz, W.P., Leedle, J.A., Allman, J.G., 2002. Ruminal supplementation of direct-fed microbials on diurnal $\mathrm{pH}$ variation and in situ digestion in dairy cattle. J. Dairy Sci. 85, 429-433.

N.R.C., 2001. The nutrient requirements of dairy cattle, 7 ed. Nat. Acad. Press, Washington D.C.

Postgate J.R., Hunter J.R., 1964. Accelerated death of Aerobacter aerogenes starved in the presence of growth-limiting substrates. Journal of General Microbiology 34, 459-473.

Roa, M.L., Barcena-Gama, J.R., Gonzales, M., Mendoza, M., Ortega, M.E., Garcia, B., 1997. Effect of fiber source and a yeast culture (Saccharomyces cerevisiae) on digestion and the rumen environment in the rumen of cattle. Anim. Feed Sci. Technol. 64, 327-336.

Russell, J.B., Hespell, R.B., 1981. Microbial rumen fermentation. J. Dairy Sci. 64, 1153-1169.

Stokes, M.R., Bull, L.S., Halteman, W.A., 1985. Rumen liquid dilution rate in dairy cows fed once daily: effects of diet and sodium bicarbonate supplementation. J. Dairy Sci. 68, 1171-1180.

Tajima, K., Aminov, R.I., Nagamine, T., Matsui, H., Nakamura, M., Benno, Y., 2001. Diet-dependent shifts in the bacterial population of the rumen with Real-Time PCR. Appl. Environ. Microbiol. 67, 2766-2774.

Vaque, D., Casamayor, E.O., Gasol, J.M., 2001. Dynamics of whole community bacterial production and grazing losses in seawater incubations as related to the changes in the proportions of bacteria with different DNA content. Aquat. Microb. Ecol. 25, 163-177.

Wallace, R.J., 1996. The mode of action of yeast culture in modifying rumen fermentation. In: Lyons, T.P., Jacques, K.A. (Eds.), Biotechnology in the Feed Industry. Proc. of Alltech's 12th Ann. Symp. Nottingham Univ. Press, Nottingham, United Kingdom, pp. 217-232.

Weimer, P.J., 2001. Microbiology of the dairy animal. In: Marth, E.H., Steele, J.L. (Eds.), Applied Dairy Microbiology. CRC Press, Cleveland, pp. 1-153.

Wells, J.E., Russell, J.B., 1996. Why do many ruminal bacteria die and lyse so quickly? J. Dairy Sci. 79, 1487-1495.

Wiedmeier, R.D., Arambel, M.J., Walters, J.L., 1987. Effect of yeast culture and Aspergillus oryzae fermentation extract on ruminal characteristics and nutrient digestibility. J. Dairy Sci. 70, 2063-2068.

Zhang, T., Fang, H.P., 2004. Quantification of Saccharomyces cerevisiae viability using Baclight. Biotechnol. Lett. 26, 989-992.

Yea-Sacc ${ }^{1026}$, Alltech, Inc., Nicholasville, KY. 